Egonne Roth

Egonne Roth (Ph.D., Bar-Ilan) is affiliated to the Department of

English of Bar-Ilan University, Ramat Gan, Tel Aviv, Israel.

Email: eeeroth@hotmail.com
Lessons in writing the biography of the crossover poet, Olga Kirsch

\title{
Lessons in writing the biography of the crossover poet, Olga Kirsch
}

Olga Kirsch was an English-speaking Jewess who wrote and published poetry in Afrikaans. As such she exemplifies a crossover poet who introduces the voice of the other into a national canon - in her case, the only Jewish voice in Afrikaans poetry. Three questions were raised in the research and writing of her biography. The first concerns the extent to which she, as a Jew, was influenced by the dominant culture in which she grew up. The second seems more complex: What influence has Olga Kirsch had on the dominant culture - was she able to influence the South African Afrikaans culture and literature in any way? Third, to what extent does the multi-culturalism of Kirsch affect the process of research and writing her biography; are there problems specific to writing the biography of a cross-cultural writer? Keywords: Afrikaans poetry, cross-culturalism, Judaism, life writing, literary influence, Olga Kirsch.

\section{Lessons in writing the biography of the crossover poet, Olga Kirsch}

Olga Kirsch holds a unique place in Afrikaans literature. As an English-speaking Jewess who chose to write and publish poetry in Afrikaans, Kirsch offers a fine example of a crossover poet, i.e. a poet who introduces the voice of the other into a national canon. Problems in defining the making of a national canon have been discussed since earliest times by such literary critics as the Greek, Longinus, through to modern times with writers such as Harold Bloom and Frank Kermode. Minnaar in his doctoral thesis regards D. J. Opperman as the most authoritative voice in shaping the Afrikaans poetry canon referring to him as "ons aartskanoniseerder" ("our arch canoniser", 229). Kirsch appears in each edition of the Groot Verseboek (The Great Book of Verse) from 1967 through to 2000 and 2008 when it appeared under the editorship of André P. Brink. Hers is the only Jewish voice in Afrikaans poetry (Roth 108). Yet, when J. C. Kannemeyer, the Afrikaans literary historian, suggested in 2009 that I write a biography of Kirsch's life I was surprised to learn how little biographical information existed. Furthermore, the sources that I found often differed with regards to the basic facts. For example, Kannemeyer (226) writes that she emigrated to Israel in 1949 while Hugo (9-15) asserts correctly that it was in 1948. As Kirsch's biographer I quickly understood that the task I had taken on would be challenging. 


\section{Biographical background}

Kirsch was born into a Jewish family in the tiny village of Koppies in the Orange Free State Province of South Africa in 1924. Koppies (originally Kopjes, i.e. hills at 27 14S, 27 35E) was founded in 1904 by General C. R. de Wet on the banks of the Renoster River, and laid out as a town for underprivileged white survivors of the Second Anglo-Boer War (1899-1902) in 1910 (Rapier 186). It was a poor village without a physical or political infrastructure or known history. Kirsch's father, a Jewish immigrant from Lithuania, arrived in Koppies around 1915, barely a decade since its founding. Sam Kirsch, having fled from poverty and the pogroms in Lithuania, shared with those already living in Koppies the experience of hardship and war. However, he brought with him a long history and culture of how to live and prosper under such circumstances. He was deeply involved in the Jewish life of the community and was instrumental in the building of the local synagogue. His wife, Eva, was the eldest daughter of a Lithuanian refugee and an English rabbi's daughter, who had come to South Africa after the outbreak of the Second Anglo-Boer War. In the home created by Sam and Eva, Olga and her siblings—-two brothers and two sisters-spoke English to their parents, but attended the local Afrikaans school. On rare occasions, her father would speak in Yiddish with his wife when he did not want the children to understand him (Hirschman). At the cheder (Jewish school) attached to the Koppies synagogue, the Kirsch children learnt Biblical Hebrew so that they could participate in the services. Olga Kirsch, like most Jewish children growing up in rural South Africa, lived in three languages: English at home, Afrikaans in the community, and Hebrew in the synagogue. As a result, they were constantly crossing over between two separate and increasingly opposed cultures-the Afrikaans Christian community and the Jewish immigrant community, each centred around its place of worship.

This illustrates Eliot's (9) belief that the relationship between culture and religion is closely intertwined and a determining factor in the shaping of that culture. By the word "culture" I understand the customs, beliefs, values that determined how a society lives and how these are expressed in its art, music and literature. Racial attitudes often flow from the religious views of a society. The interwoven nature of this relationship between culture and religion is central to a study of Kirsch's rapport with her readers as will be shown later. While anti-Semitism in South Africa during this period was not to be compared to what Sam and his co-religionists had experienced in the Russian Empire or Jews were experiencing in Europe, it was nonetheless on the rise in South Africa, sometimes incited from the pulpits of the dominant Dutch Reform Church (Milton Shain has fully dealt with this history in Roots of Antisemitism in South Africa.) Kirsch and her family experienced anti-Semitism directly when images such as swastikas were painted on the walls of Sam's shop in Koppies (Hirschman). Both her brother, Boggie, and her school friend, Arnold Shapiro, related incidents when they were beaten up by Afrikaans boys for being 
Jews (Shapiro; Kirsch, B.). Notwithstanding these incidents, the Jewish culture and traditions of Kirsch's upbringing always remained an intimate part of who she was. At the same time she continued to yearn for and draw inspiration from the landscape of her youth long after she left South Africa for Israel.

Olga Kirsch's father died just before her thirteenth birthday when she was already attending Eunice Girls' High School in Bloemfontein, the provincial capital. There Kirsch published her first poems in both English and Afrikaans in the school magazine. But it was at the University of the Witwatersrand in Johannesburg that she finally made the choice to concentrate on writing in Afrikaans. This was a conscious decision, given that the Jewish community in Johannesburg was predominantly English-speaking and, for political reasons, distanced itself from the Afrikaans community. Kirsch's daughter, Ada, has said that Afrikaans was the language of her mother's soul (Zohar) and Kirsch herself acknowledged that she was greatly influenced by the novelist and academic, C. M. van den Heever, Professor of Afrikaans-Nederlands at the university (Kirsch, "Interview"). As she was preparing the publication of her first collection of poetry, her mother tried to persuade her to do so under a pseudonym. Eva was convinced that Olga's obviously Jewish name would block any possible success. Yet Olga understood that by hiding her Jewish identity through a pseudonym, she would be silencing her own voice, the voice of a Jew. Rather, she was demanding, in a quiet but determined way, that her Afrikaans readership accept her for who she was-a Jew writing in Afrikaans. Die soeklig (The Searchlight), her first volume of poetry, was published on 8th August 1944, shortly before her twentieth birthday and before her graduation, making her only the second woman poet to publish a collection of poetry in Afrikaans. (Elisabeth Eybers had been the first when in 1936 she published Belydenis in die skemering [Confession at Dusk])

Kirsch did not directly experience the Holocaust, though as a journalist working for the infant publication of the South African Jewish Board of Deputies, Jewish Affairs, in the last years of the war, she was aware of the events occurring in Europe. By then she must also have known that her cousins on her father's side who had remained in Lithuania had been killed together with the rest of their community in 1941 (Gordon 20). Kirsch was able to internalize these facts and she writes movingly about the suffering of her people in her second volume of poetry, Mure van die hart (Walls of the Heart), published in 1948.

After the publication of this second collection, Kirsch emigrated to Israel where she lived for the remainder of her life. She married Joe Gillis, a professor of mathematics at the Weizmann Institute in Rehorot. From Israel she published another five collections of poems in Afrikaans between 1972 and 1983: Negentien gedigte (Nineteen Poems, 1972), Geil gebied (Fertile Land, 1976), Oorwinteraars in die vreemde (Hibernators Abroad, 1978), Afskeide (Farewells, 1982) and Ruie tuin (Overgrown Garden, 1983). In 1991, she self-published in Israel her only collection of English poems titled The 
Book of Sitrya. Since her death, an extensive collection of poems written in English has been discovered, some with each of her two daughters and some with her sister, Janette Hirschman. They include two collections of poems that were stapled together as if ready to be sent to a publisher as well as a large number of loose poems. The one collection of some fifty poems deals with the family sorrow resulting from her younger daughter, Ada Zohar's divorce in 1984 (Zohar) and the other is a collection of seventy-seven poems written to her beloved husband, Joe Gillis in the years following his death. ${ }^{1}$ Olga Kirsch died of metastatic melanoma in Israel in 1997, nearly four years after Joe's passing (Zohar). In one of her unpublished poems dedicated to Joe she expresses her sense of loss and loneliness:

That all our lying, sitting, walking, talking together

should come to this:

Absence, silence, a stone.

Everything the dead leave is flat:

Pictures that ape the roundedness of flesh

papers, books, clothes.

Nothing to still the hunger of the hands,

nothing for the arms to thrust against the chest,

nothing.

Silence and nothing.

Some days I could sink to the soil beside your grave

lie down

stay down.

\section{The influence of Kirsch's rural Afrikaans childhood}

Three questions presented themselves in the course of my research on Olga Kirsch as a cross-cultural poet. The first concerned how Kirsch as a Jewish poet was influenced by the dominant culture in which she grew up.

I would argue that the strongest influence that Afrikaans and life in a small, rural community had on Kirsch is evident in her nature poetry-in the love of the land, die veld. The founders of Genootskap van Regte Afrikaners had as their motto "vir ons Taal, ons Nasie en ons Land" (Kreizer). Normally translated "for our language, our nation, and our country," the word land in Afrikaans can, as in English, also refer to the physical land, the veld, the ground. The connection between the language and the physical environment as a source of personal and national identity is clear. It is found in earlier Afrikaans poetry such as in the writings of Jan F. E. Celliers, who had profound influence on the young Kirsch. A comparison of her youth poetry published in the Eunice Girls' High School Magazine with, for example, "Eensaamheid" ("Loneliness") by Celliers shows this clearly. Unfortunately, space does not allow for an extended analysis of these poems here. Dekker (267) observes that by the time she 
published Die soeklig (1948) she was no longer directly influenced by the generation of Afrikaans poets, known as the Poets of the Thirties, a view disputed by Spies (79) who points to the influence of both W. E. G. Louw and Elisabeth Eybers. Kirsch's connectedness to the physical surroundings of her childhood is reflected in much of her work such as this description of a thunderstorm above the veld:

Die eensaam hemele van my kindertyd,

God was aanwesig in hul dag en nag.

Hy't in hul bloutes wolke wit soos kryt

gestapel, aambeeldtoppe; die hamerslag

van somer-donderweer teruggehou totdat

geen wese asemhaal, geen voël durf roer.

Van ster tot sidderende ster het Hy

Sy magtige meetkunde uitgesprei

oor die swart vlak. Met Sy smal weerlig-lat

het Hy in nagte van rukwind en rumoer

my oë geteister waar ek lê omring

van engele—o veilige omsingeling!

Bo in die stormwolk God die Almagtige. (Geil gebied 15)

Minnaar (60-1) suggests that for Kirsch nature and God are closely intertwined and that, according to her daughter, Ada, references to "God" such as in the poem above are poetic "devices and not real". Rather, Kirsch finds spiritual solace in nature represented most vividly by the Free State veld with its large wide heaven. In a television documentary she said in Afrikaans, "I think it was an impressive place for a child to grow up-Koppies. The veld was so big and so flat and so wide. And the heaven was so high and the storms there were so frightening" (Yaniv). It is therefore clear why these remained central to her person and poetry for most of her life, even after she emigrated to Israel and grew to love her adopted country. In later years, she told her eldest daughter that until her first visit back to South Africa in 1975, 28 years after she had left, she dreamt of the Free State veld nearly every night (Lyons). This anecdote gains new meaning, in light of Bachelard's belief (xx) that poetry finds its origin in the subconscious and the dream space that lies between the conscious and unconscious. In fact, long after her 1975 visit to South Africa and even after she had stopped writing in Afrikaans, Kirsch was still haunted by the landscape of her childhood as is reflected in some of her later poetry. Her love of the veld is also reflected in her English poetry, most of which was probably written in the mid-1980s or later. This poem in her private collection is addressed to her husband Joe:

Why can I tell you who recall so much

nothing about the time when I grew up?

That lonely childhood 
on the vast high-plateau

where nothing stirred but the grass.

Year-long afternoons and mornings

spent wandering across the veld

bent over minute lives among straws and stalks.

Land cracked with drought,

blinding white anvil-heads,

lashing lightning under the hammer of thunder.

Great diamonded geometry of stars

and the night's desolate cry:

Hymns yearning from the far-off location,

the wail of a train striving to breach the horizon.

Several of the images in this poem also occur in Kirsch's Afrikaans poetry-the vastness of the veld, the night sky with its geometry of stars and the thunder are also present in the Afrikaans poem quoted earlier-illustrating how deeply the land was embedded in her psyche. This contrasts with the fact that Jews were traditionally not connected to the physical land in which they lived, but rather to Eretz Israel, the more abstract land of their fathers as expressed in the prayer "Next year in Jerusalem", a phrase Kirsch uses in one of her poems. ${ }^{3}$

For Kirsch, the switch from Afrikaans to English in the early eighties was brought about by the cumulative effect of two factors-the diminishing influence of Afrikaans on her after more than three decades of living in Israel and a series of family crises that demanded poetic expression in a language that could bind her more deeply to her family, none of whom spoke or understood Afrikaans.

\section{The influence of Kirsch on Afrikaans culture}

The second issue that needs to be addressed when writing about a cross-cultural poet is more complex: What influence has this poet had on the dominant culture? Did Kirsch in any way influence the dominant Afrikaans culture in South Africa? In other words, did she offer her non-Jewish readers an entry into the world of the Jew or a way of gaining greater understanding of it and have they been able to cross over this bridge?

With the exception of Hilda Grobler in her article, "Moeë Jodin 'stotter' oor vaderland" ("Tired Jewess 'stutters' about fatherland"), most critics are positive towards Kirsch's Jewishness. I. L. de Villiers delights in Kirsch's ability to not only express traditional Jewish beliefs but also modern Zionist concepts in a young language such as Afrikaans and Uys Krige, poet and journalist, comments on her ability to give voice to her Jewishness. Kirsch was not religious in the traditional sense; she was embedded in the culture and history of Judaism and the Jewish people, and after she left her parents' home she did not attend synagogue regularly. Her references 
to the Old Testament, found throughout her Afrikaans oeuvre, have been regarded as references she shared with her Afrikaans readers. In a sense this is the case, but both the spiritual and cultural meanings that these references hold for the poet often differ significantly from those of her readers. Barthes (142) wrote, "Literature is that neutral, that composite [...] where all identity is lost, beginning with the very identity of the body that writes". He purposely does not use the word "author" with its connection to the word "authority" but the more abstract "body that writes" to emphasise that the identity and biography of the writer is of no great importance and the reader's interpretation is as valid as the poet's intention. Against this view I would argue that something profound may be lost in this approach. In the case of Kirsch, what is lost is the Jewishness of the poet's referencing. This in turn may lead to erroneous conclusions as illustrated in Schutte's doctoral thesis: "Aanvanklik, in haar eerste twee bundels, het sy nog die Christelike geloof aangehang en kom dit uit in haar gedigte, maar sedert Mure van die hart begin sy 'n Joodse perspektief van haar geloof weergee..." (110) $)^{4}$ Schutte ignores the biographical information available to her and is unable to recognize the Jewish markers in Kirsch's poetry, offering a crass example of a misreading of Kirsch's work. Schutte does not indicate the basis of her Christian reading of Kirsch's poetry. In contrast, Wessels recognises that Kirsch's Jewishness is present throughout her poetry, especially in Mure van die hart. He shows the dualism underlying her work when he writes about the "Jewish poems" in this collection (Wessels 70):

Kirsch can and does rely on an intimate familiarity and even identification of her Afrikaans reading public with Old Testament history and the concepts that she invokes, but she steps beyond the familiar Christian reading of the Bible into a peculiarly Jewish evocation, shuttling between a position of intimate familiarity to her Afrikaans readership and a defamiliarizing, implicitly deliberate affirmation of her Jewish, outsider status.

Wessels illustrates this by using her poem, "Heimwee" (Mure van die hart 12):

"As ek jou vergeet, o Jerusalem, laat my regterhand dan homself vergeet".

Gee ons die land, ons het so lank gedwaal deur vreemde oorde orals, orals en jaarliks met Paasfees eeuelank herhaal: in die jaar wat kom sien ons Jerusalem.

Ek sal die land miskien nooit binnegaan nog die wat op my volg, maar is 'n volk se hoop nie tydeloos soos die hemelbaan waarin die enkeling wegsmelt soos ' $n$ wolk? 
En sal die swerwendes van alle tye nie in die tyd wat kom hul land ontvang met vreugde wat hul vrugtelose lye ewig uit die gedagtenis sal ban?

Tog bly die stille hunkering ongesus:

o land, my land, die eindelike rus. ${ }^{5}$

Wessels (68) asserts correctly that this whole poem is quintessentially Jewish with a strong Zionist theme evident throughout, but especially in the final couplet. Yet, he goes on to show that the final couplet may speak to Afrikaners not so much of Zionist aspirations in the land of Israel, but of their own fight for their land. It should be remembered that when this poem was first published, Afrikaner nationalism was rising steadily and leaders of the dominant Dutch Reformed Church played an active part in this development (Giliomee 416-7). As a result, I argue, that the Jewishness of the poem is effaced by the Afrikaner appropriation of the theme-attention has not been paid to the context of the poem as set by the epigraph. This means that the potential of using the poem to cross over into the world of Jewish experience and gain a new understanding is lost as the focus remains on the dominant culture and the reader is unable to see the world through the new and different perspective of the minority culture.

The expression 'to cross over' is used in many contexts such as crossing over a river, changing loyalties within a political situation but it is also used in tennis when players move from one side of the court to the other. In this sense it is helpful in analysing Kirsch's function as poet. In sometimes obvious and sometimes subtle ways, Kirsch offers her readership the chance to move from their side of the proverbial tennis court to the other side to see the world from a different perspective. Is the sun shining on their backs lighting up the court in front of them or is it in their eyes, blinding them? This is surely the reason why literature is translated-to allow us to see the world of the other even if through a slightly foggy lens of a translated text. Yet, through her poetry, Kirsch offers her Afrikaans readership the opportunity to experience the crossover from their culture into hers in their own language, not indirectly via translation. This may be considered one of the most precious contributions that Kirsch has made to Afrikaans, but the extent to which her wider readership has been able to appreciate this remains unclear.

Kirsch's influence on Afrikaans literature is also unclear: Lina Spies acknowledges that Kirsch influenced other Afrikaans poets in her article, "Die poësie van Olga Kirsch: Tuiskoms in vreemdelingskap" but as sole example she quotes an unpublished poem by Adam Small, "Witkalk" in which he directly addresses Kirsch (97); also Joan Hambidge has written a poem as tribute to Olga Kirsch with which I ended 
my article on the "unassimilable strangeness" of Kirsch (Roth 118). Alba Bouwer took the title of her book, Die afdraand van die dag is kil (The end of the day is cold, 1993), about aging from a poem by Kirsch in Negentien gedigte titled "Hoe het dit skielik laat geword?" ("How did it suddenly become so late?") The doctoral thesis by Minnaar, "A re-evaluation of Olga Kirsch's oeuvre: identity, maternity and exile in the light of the psychoanalytical theories of, among others, Sigmund Freud, Jacques Lacan and Julia Kristeva," has aroused interest among scholars and offers new insights to Kirsch's poetry. A thematic issue dedicated to Olga Kirsch by the journal Werkswinkel appeared in 2014 with articles by the literary critic, Louise Viljoen; the novelist Eben Venter; the poet and critic Lina Spies and the critic, Burgert Senekal amongst others. However, whether these references may be seen as signs of the distinctive influence of Kirsch on Afrikaans culture is not clear. With Kirsch not being taught in schools since 2005 (Rademeyer), the danger exists that she will slip out of the cultural consciousness and her influence will become even less.

\section{Problems in writing a cross-cultural biography}

Third, how does the multi-culturalism of Kirsch affect the process of investigating and writing her biography or how does the Jewishness of an Afrikaans poet problematize the writing of her biography?

Salman Rushdie in Midnight's Children comments on biography writing in the words of his narrator Salaam: "To understand me, you'll have to swallow a world" (457). And, elsewhere: "And there are so many stories to tell, too many, such an excess of intertwined lives events miracles places rumors, so dense a commingling of the improbable and the mundane! I have been a swallower of lives; and to know me, just the one of me, you'll have to swallow the lot as well" (14). These words haunt me as Kirsch's biographer: For every word I write, I am aware of a hundred I do not write; for every fact I give, I am aware of a hundred I do not share. This is a problem all biographers face-today no-one will publish a biography in five volumes such as Leon Edel wrote of Henry James (McCullough). Yet, there is a world we have to swallow to be able to understand our subject and, in the case of a cross-cultural poet such as Olga Kirsch, there is not simply one world, but at least two, and the multifaceted nature of these two worlds, which themselves stretch across more than one world, adds to the complexity.

It immediately became evident to me that, because the worlds that Kirsch represents do not always intersect with each other peaceably, she elicits various prejudices. In working on this project since 2010, I have realized, for example, that many in the Afrikaans community do not see themselves as anti-Semitic and wish to negate the anti-Semitism that was evident in the 1930s and 1940s when Kirsch was growing up in the rural Orange Free State. They note, for instance, that South Africa was one of the first countries to recognize the State of Israel, but they do not know the 
history of this act. Many believe it was the newly elected National Party leader, Dr D. F. Malan who did so, while in fact it was the last act by the previous government's Prime Minister, General Jan Smuts. In 1948 Smuts was the last living signatory to the Balfour Declaration and it was in this capacity that Chaim Weizmann pressured him to make this declaration. However, in his biography of his father, Smuts' son expresses the belief that this was one factor that caused his father to lose the election that took place days after Israel had become a state (Smuts 510). Later examples of cordial relations between Israel and the Republic of South Africa were often fostered for pragmatic reasons rather than friendship. Today this situation has changed and blatant anti-Semitism is again on the rise. Yet, Kannemeyer (248) emphasizes that Kirsch's importance lies in the fact that she is the only Jewish voice in Afrikaans poetry. This implies that biographers who do not fully explore the Jewishness of her life and poetry will not be fulfilling their duty, even if this problematizes publication of the biography.

Connected to the above is the second prejudice that Kirsch attracts: Writing in Afrikaans outside the Afrikaans community has also worked against her as Afrikaans is sometimes seen as 'the language of the oppressor' during the apartheid era. As with anti-Semitism, this prejudice is often based on ignorance. Kirsch experienced this in 1995 when she attended sessions of the international conference "Breaking the Boundaries: Beyond the Land of Kush. Literature and Culture in Africa South of the Sahara" at Tel Aviv University. Several members of the South African delegation tried to have Kirsch removed from the speakers' roll as she had been an Afrikaans poet (Gray). The fact that she had been one of the first Afrikaans poets to speak out against social and racial injustice in South Africa was ignored or perhaps unknown. These subtle and less subtle prejudices have to be addressed in the biography in a way that will enlighten and enrich the reader's appreciation of the poet's work without being alienating or threatening. Thus the writing of a biography of a crosscultural poet is in itself a process of crossing over between two or more cultures together with the reader.

When it became known that I was planning to write Kirsch's biography in English, some within the Afrikaans establishment objected. One potential source of information, a poet, said to me, "I can't talk to you: Kirsch was an Afrikaans poet and should not be written about in English. Sy's een van ons en nie een van julle nie. ('She is one of us and not one of yours.)" Yet it is widely acknowledged that Kirsch's home language, her mother tongue, was English and, until her Afrikaans work is translated into English and her English oeuvre becomes known, she will not receive the wider recognition she deserves, not in South Africa nor in Israel. Kirsch was not solely an Afrikaans poet. As Hugo (9-15) writes in his introduction to Kirsch's collected poems that she published part of a much longer English manuscript in the United States in 1965 , between her second and third volumes of Afrikaans poetry. Hugo also 
discusses The Book of Sitrya in his introduction and even includes an English poem from it. Therefore, the fact that Kirsch also wrote in English has been available since 1994 to any researcher, student, or reader interested in her work. While The Book of Sitrya was the only English collection published, Kirsch wrote a great deal of very beautiful poetry in English, which deserves to be read and enjoyed. If I were to deny or relegate to the side lines her unpublished English work, I would be depriving Kirsch's readership of some of her most moving poetry. Those who do not like these facts, like the Afrikaans poet mentioned above, will be dissatisfied with my biography. However, I believe that as tribute to the loyalty of many of Kirsch's Afrikaans readers, a translation of the biography into Afrikaans is essential. As far as is known, Kirsch wrote only eight Hebrew poems-not enough to receive recognition as an Israeli Hebrew poet, but according to Hebrew readers that I asked to evaluate these poems, they possess the same elegant simplicity that characterizes her best Afrikaans poetry.

Language has always been a marginalizing factor in Kirsch's life, a thread that needs to run through the biography. In this context, the Chicana poet Gloria Anzaldúa's concept of mestizaje-being beyond binary ("either-or") conceptualization, a state of multiple identities-is relevant. Kirsch was always aware of her conflicting and meshed identities and the pain this caused her, as she wrote:

My lewe sal gesplete bly:

Groen stamme as die byl hul kap

kerndiep, sal nooit weer heelheid kry.

Maar aan die staallem klewe sap. ${ }^{6}$ (Geil Gebied 6)

Another problem that I face in writing this biography deals with an aspect of crossculturalism that I had not anticipated. When I explain Jewish elements either in the poetry or the biography of Kirsch, a Jewish reader assures me that much of this will be known to the readership of the biography. To the Jewish readers these elements may be obvious, though some differences do exist between being a Jew in South Africa in the 1930s and 1940s and being a Jew in the United States. Having grown up in the Afrikaans Dutch Reformed Church culture, I am intimately familiar with what Kirsch's Afrikaner readership knows and does not know about Jewish culture. I know the subtle forms of appropriation-how the Old Testament is read and used. Having grown up in the Afrikaans world, living in the Orange Free State, and then converted to Judaism, I also understand that these forms of subtle appropriation sometimes lead to blatant anti-Semitism, often based on ignorance of what Jews really believe and how they express these beliefs in their customs and rituals. As a result, I know what needs to be explained to the non-Jewish reader of Kirsch's poetry.

What I initially did not even think about is the extent to which South Africa and the world of the Afrikaner that Kirsch loved in so many ways is not known to English readers, and sometimes even to South African Jews. For example, Kirsch 
loved Afrikaans food; her older daughter once told me jokingly that she sometimes thought her mother would have sold her soul for a good koeksister, a (very) sweet plaited delicacy, although she herself had no real understanding why her mother loved it so much. After all, Arabs in Israel also make sweet syrupy cakes and she could not understand why they did not satisfy her mother's need. I do. They are simply not the same- - these sweet things are not plaited and the local syrup is often flavoured with rose water, not orange or lemon peel as in the Free State. While this may seem a trivial example, food remains an intimate part of cultural identification and an alienating factor for an immigrant. Thus, it is important for a biographer to help the reader understand these cultural references. Kirsch's younger brother Boggie maintained that veld referred to more than simply "land" but also to the vastness, the smells and sounds, fauna and flora specific to their Orange Free State childhood (Kirsch, B.). Initially I failed to recognize that these references may be unfamiliar to readers and potentially problematic. In this sense, the very act of writing this biography has become a bridge between two opposing cultures.

Finally, as the writer of a literary biography, where literary referencing and analysis are important, I must never lose sight of the fact that I am telling the story of someone's life-of a person who as poet or writer had a public persona while at the same time was a private person experiencing every day interactions with those she loved, colleagues, or simply acquaintances. The interactions among all the diverse strands that informed her work have to be explored in a way that will make the person on the page come alive for the reader. Edel writes "A biography seems irrelevant if it doesn't discover the overlap between what the individual did and the life that made this possible. Without discovering that, you have shapeless happenings and gossip" (McCullough). To be able to discover and portray this overlap, it is necessary for the biographer not only to swallow all those worlds cited by Rushdie, but to digest and reproduce them in a way that will reflect what Irvin Yalom, the American existential psychiatrist, describes as "the unknowability of the other", the "inexhaustible complexity" of the other (184). It is this unknowability and inexhaustible complexity that presents the biographer with the most daunting challenge and, when successfully portrayed, offers the reader with the most rewarding read.

\section{Notes}

1. There were no unpublished Afrikaans poems found in the possession of Kirsch's family, only English poems, none of which were dated. I dated many of these poems by comparing their content to biographical information that surfaced in my research. Where a direct correlation between life and content was not clearly evident, I discussed the poems with Kirsch's daughters and her sister and also took into consideration comments made by Kirsch in various interviews. It would seem that in the period immediately after Kirsch's mother's death, she was experimenting with writing in three languages, Afrikaans, English and Hebrew as a number of poems exist with similar subjects, mainly her mother's funeral. Comparing the poems that refer to the same events written in these languages would be an interesting subject for a separate article.

2. "The lonely heavens of my childhood, / God was present there day and night. / He stacked clouds white as chalk / in their blueness, anvil masses; the hammer / of summer thunder withheld until / no 
creature breathed, no bird dared stir. / Star to shuddering star He / spread out His mighty geometry / across the black plane. With His lightning whip / in nights of windstorm and uproar / He plagued my eyes where I lay surrounded / by angels_-oh safe encirclement! / Above the storm clouds God the Almighty." My translations from the original Afrikaans unless stated otherwise.

3. One reason for this may be that, in many countries, Jews were not given citizenship until recently, often not allowed to own property, and could be expelled from their countries of residence at the whim of the reigning power. History is replete with examples of this. Therefore, becoming too deeply attached to the physical land would have been foolish, hence learning took on extraordinary importance.

4. "Initially, in her first two collections, Kirsch was still a supporter of the Christian faith and this is clear from her poems, but with Mure van die hart she begins to reflect a Jewish perspective in her faith..." (Schutte 110)

5. "Nostalgia": "'If I forget thee, O Jerusalem, let my right hand forget itself' Give us the land, we have wandered so long / through foreign places everywhere, far and wide / every Passover through the centuries we have repeated: / in the year to come we shall see Jerusalem// I may perhaps never enter the land / nor even those who follow me, but is a people's / hope not timeless like heaven's celestial band / in which one person melts away as a cloud? // And will be the wanderers of all times / not received their land in due course / with joy that bans their fruitless sufferings / forever from their thoughts? // Yet the silent yearning unfulfilled:/ O land, my land, the final rest." (Wessels' translation).

6. "My life divided will remain: / Green trunks, when the axe chops / to the core, will never wholeness gain. / But to the steel blade sap will cling."

\section{Works Cited}

Anzaldúa, Gloria. Borderlands/La Frontera: The New Mestiza. 3rd ed. San Francisco: Spinsters/Aunt Lute, 1987. Barthes, Roland. Image Music Text. Trans. S. Heath. London: Fontana Press, 1977.

Bachelard, Gaston. The Poetics of Space. Boston: Beacon Press, 1994 [1958].

Celliers, Jan F. E. Die vlakte en ander gedigte. Cape Town: Nasionale Pers, 1934.

De Villiers, I. L. “Olga Kirsch: sangeres van Sion.” Die Vaderland, 9 Oct. 1975.

Dekker, G. Afrikaans literatuurgeskiedenis. Cape Town: Nasionale Boekhandel Bpk, 1960.

Eliot, T. S. Notes Towards the Definition of Culture. London: Faber and Faber, 1948.

Giliomee, Hermann. The Afrikaners: Biography of a People. Cape Town: Tafelberg; Charlottesville: U of Virginia P, 2003.

Gordon, Lyndall. Divided Lives: Dreams of a Mother and Daughter. London: Virago, 2014.

Gray, S. Interview with E. Roth. Johannesburg, July 2010.

Grobler, H. “Moeë Jodin 'stotter' oor vaderland." Hoofstad, 4 Jan. 1979.

Hirschman, J. (Sister of Olga Kirsch). Interviews with E. Roth. Jerusalem, May 2010-Dec. 2014.

Hugo, Daniel, ed. Nou spreek ek weer bekendes aan: 'n Keur 1944-1983. Cape Town: Human \& Rousseau, 1994.

Kannemeyer, J. C. Die Afrikaanse literatuur 1652-1987. Cape Town: Human \& Rousseau, 1988. . Die Afrikaanse literatuur 1652-2004. Cape Town: Human \& Rousseau, 2005.

Kirsch, Bernard. Telephonic interviews with E. Roth, Jan. 2010.

Kirsch, Olga. Die soeklig. Pretoria: J. L. van Schaik, 1944. . Geil gebied. Cape Town: Human \& Rousseau, 1976.

Interview with Hennie Maas. Skrywers en boeke. Radio Suid-Afrika. Johannesburg. T89/918-

919,1989. Recording. . Mure van die hart. Johannesburg: Afrikaanse Pers Boekhandel, 1948.

. Private collection of unpublished poems. Manuscript.

."Sononder." Eunice Girls' High Magazine, 1941. Poem.

. The Book of Sitrya. Rehovot: Self-publication, 1990.

Kreitzer, Amanda. "Die Genootskap van Regte Afrikaners". De roepstem / Die roepstem. 20 Aug. 1999. 16

Sept. 2015. < http://www.roepstem.net/patriot.html>.

Krige, Uys. "Olga Kirsch: 'n merkwaardige ontwikkeling." Books and Writers: Jewish Book Festival, 1948.

South African Jewish Board of Deputies. 1948.

Lyons, Michal. (Daughter of Olga Kirsch). Interviews with E. Roth. London, May 2010-Aug. 2013.

Minnaar, William Frank Thomas. 'n Herwaardering van Olga Kirsch se oeuvre: Identiteit, moederskap en 
ballingskap aan die hand van die psigoanalitiese teorieë van onder andere Sigmund Freud, Jacques Lacan en Julia Kristeva. PhD diss, U of Cape Town. 2012.

McCullough, Jeanne. "Leon Edel, The Art of Biography No. 1. Interviewed by Jeanne McCullough". The Paris Review 98 (1985). 9 Jun. 2015. < https://www.theparisreview.org/interviews/2844/leon-edel-theart-of-biography-no-1-leon-edel $>$.

Rademeyer, P. Interview with E. Roth. Koppies, Sept. 2013.

Rapier, Peter E. New Dictionary of South African Place Names. Johannesburg, Cape Town: Jonathan Ball, 2004.

Roth, Egonne. “Unassimilable strangeness: The Afrikaans Poetry of Olga Kirsch.” Werkswinkel 8.1 (2013): 101-21.

Rushdie, Salman. Midnight's Children. 1981. London: Vintage Books, 2006.

Schutte, S. E. Die uitbeelding van die dood in die digkuns van Elisabeth Eybers, Olga Kirsch en Eveleen Castelyn. DLitt et Phil diss, U of South Africa, 2004.

Shain, Milton. The Roots of Antisemitism in South Africa. London and Charlottesville, VA: U P of Virginia. 1994. Shapiro, Arnold. Interviews with E. Roth. Koppies, Aug. 2009-Aug. 2010.

Spies, Lina. "Die poësie van Olga Kirsch: Tuiskoms in vreemdelingskap." Werkwinkel 9.2 (2014): 73-98.

Smuts, J. C. Jan Christiaan Smuts by his Son. London: Cassel \& Co., 1952.

Van Bork G. J. \& P. J. Verkruijsse, eds. 1985. De Nederlandse en Vlaamse auteurs van middeleeuwen tot heden met inbegrip van de Friese auteurs. De Haan, Weesp. 1985. 9 Jun 2015. <http://www.dbnl.org/tekst/ bork001nede01_01/bork001nede01_01_0879.php>.

Wessels, Andries. "The outsider as insider: The Jewish Afrikaans Poetry of Olga Kirsch". Prooftexts 29.1 (2009): 63-85.

Yalom, Irvin D. Love's Executioner. 1989. New York: Basics Books, 2012.

Yaniv, Y. Digter Olga Kirsch. Narrator: Roelf Jacobs. Producers: David Goldstein \& Alik Vatikay; dubbed for SABC by Van T-films. Herzliya, Israel: United Studios of Israel, 1984. Video.

Zohar, Ada. (Daughter of Olga Kirsch). Interviews with E. Roth. Jerusalem, May 2010-Dec. 2014. 